\title{
Strategi Pengelolaan Materi Musikal dan Teknis Paduan Suara; Studi Kasus Pengalaman Aktivitas Pentas, Lomba, dan Penjurian
}

\author{
A. Gathut Bintarto T. \\ Jurusan Musik; FSP Institut Sei Indonesia Yogyakarta, 0877-39781571, bintarto_853@yahoo.com
}

\begin{abstract}
This research tried to figure out the complexity of challenges faced by the choir's conductor or the vocal coacher especially to comprehend deeply in the certain period the matters that can be observed to gain the optimum results that can be measured significantly by the choir's member. The early musical strategic found in the beginning of this research trying to capture the activities of the vocal coacher based on the experiences found by the researcher during the preparation period to make the choir's performances or as in the position as a choir's judge in the middle of the contest. The participated observation conducting in this research shown the datas of similar process and the final expectation between the short (1 week to 2 months), middle (2,5-4 months) and long period (more than 5 months) of the preparations. The supporting data collected in this research shown that the imaginative abilities dan the experiences of the vocal coacher in coping with the different situations of the performances and the contests brought significant effects for conducting the song's material, working with various rhythmical patterns, interpreting the music and for sharing the musical ideas as they processed in one or multiple events at one time.
\end{abstract}

Keywords: musical strategy, preparing duration, target orientation, choir's technique.

\begin{abstract}
Abstrak
Penelitian ini mencoba memaparkan luasnya cakupan yang harus dihadapi oleh seorang penggiat olah vokal terutama untuk melihat dengan lebih jeli dalam rentang waktu tertentu hal-hal yang bisa dilakukan untuk mendapatkan hasil yang optimal dengan perubahan yang cukup signifikan yang dirasakan oleh anggota paduan suara. Strategi pengelolaan materi musikal yang ditemukan dalam penyusunan awal laporan penelitian ini lebih banyak menyorot aktivitas yang dihadapi oleh para penggiat olah vokal secara umum terutama berdasarkan pengamatan yang dilakukan peneliti selama proses persiapan maupun penjurian tersebut berlangsung. Pendekatan observasi partisipan yang dilakukan dalam penelitian ini menunjukkan sebuah perbandingan pengelolaan proses dan hasil akhir yang serupa dalam jangka waktu pendek (1 minggu - 2 bulan), menengah (2,5 - 4 bulan) dan panjang (lebih dari 5 bulan). Data dukung yang dikumpulkan menunjukkan aktivitas yang memperlihatkan bahwa kemampuan imajinatif dan pengalaman penggiat olah vokal dalam menghadapi berbagai situasi lomba dan pentas membawa pengaruh yang cukup signifikan terhadap pengelolaan strategi musikal seperti cara penyampaian materi lagu, pengolahan varian ritmis, interpretasi musik serta pembagian pengalaman maupun ide-ide musikal kepada para anggota pada saat menghadapi satu atau beberapa event paduan suara sekaligus.
\end{abstract}

Kata Kunci: strategi musikal, waktu persiapan, orientasi target, teknis paduan suara

\section{Pendahuluan}

\section{Latar Belakang}

Aktivitas paduan suara telah merambah ke berbagai kalangan dan institusi di Indonesia. Kebutuhan terhadap aktivitas seperti ini pada umumnya dipakai sebagai sebuah acara puncak dalam rangka memperingati hari ulang tahun atau ajang silaturahmi yang dikelola secara bersama-sama oleh berbagai pihak yang saling berkaitan dari sebuah institusi. Acara seperti ini selalu menarik perhatian karena mau tidak mau 
sifat alami aktivitas ini melibatkan banyak orang dan pada umumnya berbentuk sebuah pentas atau lomba. Setiap orang menantikan aksi-aksi yang akan ditampilkan oleh para peserta yang nota bene tidak terlalu akrab dengan dunia paduan suara dalam aktifitas keseharian mereka. Pertunjukan yang ditampilkan menjadi kejutan menarik dan merupakan salah satu sarana hiburan bagi semua pihak yang terlibat.

Beberapa aktivitas paduan suara seperti itu bahkan telah dilakukan selama beberapa periode dan selalu mengalami pasang surut dalam penyelenggaraannya. Beberapa lembaga atau institusi yang dapat disebutkan disini adalah Badan Koordinasi Keluarga Berencana Nasional (BKKBN) Daerah Istimewa Yogyakarta yang berusaha menggalakkan kembali program nasional keluarga kecil bahagia dan sejahtera melalui penyelenggaraan Lomba Paduan Suara Mars Keluarga Berencana pada sekitar bulan Juni setiap tahun. Lembaga lain yang juga menyelenggarakan aktivitas lomba secara berkala adalah Fakultas Kedokteran Universitas Gadjah Mada bekerjasama dengan Rumah Sakit Dr. Sardjito.

Aktivitas pentas maupun lomba paduan suara semacam itu sangat banyak dan saat ini tidak terbilang jumlahnya. Salah satu ragam aktivitas paduan suara yang sering digunakan sebagai ajang pentas atau lomba adalah vokal group. Aktivitas paduan suara ini melibatkan anggota yang relatif lebih kecil dari sebuah paduan suara dengan kisaran jumlah 5 - 12 orang untuk setiap kelompok. Instrumen akustik menjadi sebuah ciri khas iringan yang umumnya melibatkan instrumen seperti gitar, biola, seruling, pianika, cajun, maracas atau bahkan instrumen perkusif seperti gamelan. Para penyanyinya tak jarang mendobel peran sebagai pemusik dan mereka merancang berbagai koreografi pendukung pertunjukan sebagai sebuah atraksi yang menjadi nilai tambah kualitas penampilan.
Kota Yogyakarta sebagai kota pelajar bahkan telah memicu aktivitas paguyuban keluarga mahasiswa dari luar daerah seperti dari Kalimantan untuk membentuk Forum Himpunan Pelajar Mahasiswa Kalimantan dan mengadakan Pesta Seni dan Budaya Dayak Se-Kalimantan di Yogyakarta dan memasukkan lomba vocal group sebagai salah satu mata acara yang paling menarik minat penonton setiap tahunnya. Penyelenggaraan yang diadakan yang pada tahun 2014 kemarin telah mencapai yang ke-12 dengan jumlah peserta yang semakin meningkat.

Sebagai lembaga negara yang berkepentingan langsung terhadap pelestarian seni budaya dan tradisi yaitu, Kementerian Pendidikan dan Kebudayaan, telah mengadakan suatu program untuk meningkatkan apresiasi seni budaya daerah melalui sebuah ajang lomba Festival Lomba Seni Siswa Nasional (FLS2N). Lomba ini selalu diselenggarakan setiap tahun dan salah satu bentuk lombanya adalah vokal group. Acara ini bertujuan menjaring bibit-bibit unggul pelaku seni terbaik dari setiap daerah di Indonesia dan dilakukan melalui seleksi tingkat daerah terlebih dahulu.

Berbagai ajang lomba paduan suara yang dipaparkan diatas merupakan sebagian kecil lahan persemaian pelaku kesenian yang baru dan ajang pembelajaran yang efektif bagi para penggiat olah vokal. Tidak sedikit alumni dari Jurusan Musik Fakultas Seni Pertunjukan ISI Yogyakarta yang terlibat langsung dalam ajang lomba tersebut. Keindahan pertunjukan yang dinikmati sebagai hasil akhir menyamarkan proses perjuangan para anggota beserta pelatih dan kru dalam suatu kelompok dan berbagai aktivitas serta jerih payah yang telah mereka lalui. Banyak aspek persiapan dan pertunjukan yang tidak jarang terlewatkan atau belum terpikirkan secara maksimal dalam mencapai tujuan oleh para pelakunya.

Kegiatan pentas maupun lomba yang selalu berulang dalam suatu periode tertentu 
menampilkan suatu aktifitas yang dinamis dari berbagai kelompok yang telah berulang kali mengikuti atau mempergelarkan. Kenyataan lain menunjukkan bahwa proses belajar mengolah suara dalam kerangka paduan lebih banyak dipelajari melalui apresiasi terhadap penampilan kelompok lain langsung pada saat pentas maupun lomba. Pencapaian prestasi menjadi sebuah hal yang bersifat situasional karena berbagai faktor yang mempengaruhi proses mulai dari persiapan, perancangan latihan hingga sampai pelaksanaan pada hari H. Pertimbangan pada berbagai detil persiapan dan penampilan menjadi sebuah sarana untuk memperbesar kesempatan mencapai hasil penampilan puncak yang terbaik. Hal tersebut kemudian memberikan inspirasi untuk memberikan suatu sumbangan pemikiran yang nantinya dapat dijadikan rambu-rambu untuk menghasilkan suatu kualitas pertunjukan yang optimal dengan memperhatikan berbagai segi kenyamanan dalam persiapan maupun pentas.

Berdasarkan uraian di atas, peneliti merumuskan beberapa permasalahan yang akan diteliti yaitu materi ajar paduan suara melalui penelitian ini sebagai berikut:

a. Pertimbangan dan pengembangan faktor musikal apa saja yang menjadi fokus perhatian dalam pencapaian prestasi paduan suara dalam suatu lomba?

b. Bagaimanakah strategi pengelolaan sebuah komunitas paduan suara untuk mencapai penampilan akhir yang terbaik?

\section{Tinjauan Pustaka: Antisipasi Situasi dalam Pengolahan Paduan Suara}

Studi olah vokal yang berkaitan dengan paduan suara mencakup aspek yang lebih luas dari olah vokal secara individual karena perpaduan suara manusia membutuhkan sebuah pendekatan yang tidak hanya dilakukan secara personal namun juga se- cara komunal. Tidak jarang perpindahan posisi dari penyanyi menjadi pelatih membutuhkan adaptasi yang perlu dilakukan secara cermat namun efektif mengingat waktu persiapan pentas yang dapat dikatakan relatif terbatas. Tindakan yang bersifat adaptasi dan antisipasi situasional tersebut menjadi bagian penting yang akan digali dan hal tersebut membutuhkan referensi awal dari beberapa penelitian terdahulu.

Penelitian mengenai komunitas paduan suara sudah pernah dilakukan oleh beberapa peneliti. Desti Indrawati, mahasiswa mayor vokal klasik Jurusan Musik FSP ISI Yogyakarta dalam penelitiannya menulis mengenai sebuah kelompok paduan suara anak Vocalista Angels di daerah Klaten Jawa Tengah yang diasuh oleh alumnus Jurusan Musik Yason Christy Pranowo. Paduan suara ini sudah terkenal dengan prestasinya yang mendunia. Beberapa kunci sukses mereka dipaparkan dan dapat digunakan sebagai salah satu referensi. Hasil penelitian berikutnya mengenai paduan suara dilakukan oleh Endang Ismudiati yang menyorot aktivitas paduan suara untuk para lansia di sebuah Gereja Kristen Indonesia di daerah Yogyakarta pada tahun 2011. Hasil penelitian yang dituangkan dalam Jurnal Promusika tahun 2014 ini menyorot sebuah Komunitas paduan suara yang memiliki sebuah karakter spesifik mengenai keanggotaan yaitu menyangkut usia para anggota dan sikap bernyanyi. Paduan suara lansia tersebut memiliki sebuah tujuan yang berbeda dari hasil penelitian Desti meskipun keduanya mempunyai peran umum yang sama sebagai sebuah komunitas penyalur hobi.

Lagu yang berbeda, situasi yang berbeda, dan anggota yang berbeda membutuhkan penanganan yang berbeda pula. Namun demikian tentu saja terdapat suatu kesamaan yang dapat digali dari penelitian awal tersebut yang akan dikembangkan pada penelitian ini. 
Menangani paduan suara lansia dan paduan suara anak membutuhkan pemikiran yang cermat mengenai materi lagu yang akan dipelajari. Antisipasi para pelaku paduan suara terutama pelatih terhadap situasi dalam latihan yang belum terekam secara jelas merupakan bagian dari penyelidikan dalam penelitian ini.

John Howkins, salah seorang pengamat ekonomi Amerika yang menulis buku "Creative Economy, How People Make Money from Ideas" memasukkan musik sebagai salah satu bidang yang berpengaruh dalam menggerakkan roda ekonomi masyarakat modern melalui penjualan gagasan. (Afiff, 2012:1) Masyarakat sekarang digerakkan oleh suatu kebutuhan akan industri kreatif yang mengacu pada suatu aktivitas ekonomi yang mengarah pada pembangkitan atau pengeksploitasian pengetahuan dan informasi. Musik sebagai materi ajar memiliki dimensi edukasi yang bersifat universal. Hal ini sesuai dengan ungkapan sosiolog Emile Durkheim yang dikutip oleh Drummond (Campbell, 2005: 1) bahwa pendidikan merupakan sosialisasi individual kepada aturan-aturan tak tertulis bersama dari suatu masyarakat. Lebih lanjut diungkapkan oleh Drummond bahwa unsur pendidikan dalam musik mencerminkan, menyaring, dan menjabarkan nilai-nilai musikal.

Aktivitas berolah vokal sebagai aktivitas musikal mempunyai berbagai macam aspek yang dapat dikaji dalam kerangka pengembangan ketrampilan individu yang disesuaikan dengan perkembangan jaman. Beberapa kriteria pengolahan yang mulai mendapat perhatian lebih luas berkaitan dengan aspek kenyamanan, estetika penampilan dan koordinasi pertunjukan mulai dari persiapan, pelaksanaan hingga pasca pelaksanaan. Dalam hal ini pendidikan musik memiliki keuntungan praktis seperti yang diungkapkan oleh Drummond (2005:
3) yang mengacu pada pandangan Schipper dan Kors yaitu bahwa pendidikan musik dapat mempersiapkan musisi muda secara lebih baik untuk menghadapi aktivitas musikal professional pada dekade yang akan datang.

Para pendidik seharusnya mampu membuat para pembelajar musik bersiap siaga menghadapi berbagai macam manifestasi musik di msayarakat. Pendidikan musik semestinya bertujuan untuk memungkinkan mereka bertahan pada dunia yang penuh dengan pilihan, menghubungkan aktivitas mereka pada berbagai macam musik dan pendengar yang selalu berubah dalam memilih musik yang mereka minati. Paduan suara sebagai salah satu bagian dari pendidikan musik memiliki dimensi seni yang merupakan cerminan dan bentuk norma sosial. Pandangan tersebut merujuk pada pendapat Louhivuori yang mengacu pada pandangan Putnam mengenai 3 komponen modal sosial yaitu: (a) nilai dan norma, (b) komunitas dan (c) kepercayaan. (Campbel 2005: 83) Pendapat tersebut melatarbelakangi penjabaran berikutnya yaitu bahwa paduan suara, orkestra atau kelompok lain yang menggunakan musik sebagai hobi merupakan ekspresi komunitas.

Melalui hobi yang telah dimulai sejak masa kanak-kanak seseorang dapat mempelajari cara bertindak yang penting yang nantinya dapat membantu dalam membentuk jejaring sosial. Dalam kerangka yang lebih luas bergabungnya seseorang dalam sebuah keanggotaan paduan suara memungkinkannya untuk berhadapan dengan anggota lain dari berbagai kalangan, suku maupun budaya masyarakat. Hal tersebut memungkinkan anggota paduan suara untuk saling belajar mengembangkan kepercayaan yang dibutuhkan dalam mencapai tujuan yang lebih besar seperti pentas atau lomba. 
Tujuan untuk membentuk kelompok paduan suara yang terlatih menurut Thomas Turino (2008:26) dalam tulisannya berjudul Music As social Life, The Politics of Participation tergolong dalam kategori presentational participant. Kategori kelompok ini menyiapkan dan menyediakan musik untuk kelompok lain atau penonton yang tidak ikut berpartisipasi dalam pembuatan musiknya. Lebih lanjut dinyatakan bahwa tujuan, nilai-nilai, praktik, dan gaya dari setiap pelaku dalam suatu wilayah musik akan dibentuk oleh konsepsi mereka mengenai ideologi dan konteks penerimaan dan tujuan bermusik dalam bidang yang mereka geluti. Oleh karena itu sikap dalam mempersiapkan dan memainkan musik dalam suatu partisipasi musik akan sangat bervariasi menyesuaikan tujuan kelompok.

\section{Tujuan dan Manfaat Penelitian}

Penelitian ini akan menghasilkan data penelitian yang dapat digunakan untuk tujuan praktis, yaitu :

a. untuk mengetahui unsur-unsur musikal yang berperan penting dalam proses pengelolaan materi kegiatan paduan suara baik untuk pentas maupun lomba berdasarkan pertimbangan prestasi yang ingin dicapai kelompok,

b. untuk mengetahui faktor penunjang yang bersifat teknis situasional namun berdampak cukup besar dalam menentukan hasil akhir target,

c. dan untuk mengetahui langkahlangkah sistematik bagi anggota, pelatih, dan pengelola paduan suara agar proses keiatan dapat berjalan optimal dari awal perancangan hingga akhir pelaksanaan.

Penelitian ini diharapkan mampu memberikan kontribusi bagi para penggiat olah vokal secara umum dan mahasiswa yang mengambil mata kuliah ensambel vokal secara khusus di lingkungan Jurusan
Musik FSP ISI Yogyakarta. Hasil penelitian ini akan membantu para penggiat olah vokal paduan suara untuk memberikan informasi serta wawasan yang lebih luas mengenai kegiatan berpaduan suara yang selama ini telah dilakukan.

\section{Metode Penelitian}

Penelitian dalam tulisan ini menggunakan Metode Penelitian Kualitatif dengan pendekatan studi kasus. Menurut Robert K. Yin (2003: 2), studi kasus sebagai sebuah strategi penelitian dapat digunakan untuk penelitian lapangan yang salah di antaranya mengjkaji studi-studi organisasi dan manajemen. Paduan suara sebagai sebuah aktivitas kelompok membutuhkan pengelolaan aktifitas interaktif antar pelakunya dan dalam hal ini peneliti memilih menggunakan pendekatan participant observation. Pendekatan observasi partisipatif tersebut mengacu pendapat Harris (Creswell, 1998:58) yang memaparkan strategi peneliti menelaah pola-pola perilaku, kebiasaan, dan gaya hidup kelompok yang diteliti sekaligus jika dimungkinkan terlibat secara langsung dalam berbagai aktivitas didalamnya. Penggunaan pendekatan studi kasus seperti yang dijelaskan lebih lanjut oleh Yin (2003: 12) lebih dikehendaki untuk melacak peristiwa-peristiwa kontemporer.

Objek penelitian adalah para penggiat olah vokal yang ada di Yogyakarta dan sekitarnya yang telah berkecimpung secara aktif dalam dunia olah vokal paduan suara serta memiliki pengalaman dalam mengelola paduan suara untuk keperluan pentas maupun lomba maupun berperan sebagai juri. Alat bantu yang digunakan untuk mempertajam pembahasan adalah form penjurian, dokumentasi audio visual dan panduan pengetahuan dari beberapa referensi buku yang memuat capaian aspekaspek estetik musik paduan suara.Analisis data dilakukan dengan menggunakan 
metode komparatif. Watanabe (1967: 5) menjelaskan metode komparatif sebagai pembandingan beberapa elemen yang memiliki kesamaan dan elemen-elemen yang memiliki perbedaan. Metode tersebut mendukung strategi analisis yang diungkapkan oleh Yin (2003: 140) yaitu logika penjodohan pola. Berdasarkan pandangan di atas, analisis dalam penelitian ini dilakukan melalui perbandingan fenomena yang terjadi pada beberapa acara pentas atau lomba yang dihadapi oleh para penggiat olah vokal. Prosedur yang dilakukan adalah mencari persamaan dan perbedaan pengelolaan aspek musikal dan teknis mulai dari persiapan, proses, dan hasil akhir dari setiap posisi atau peran musikal yang diambil dari para responden dan merumuskannya menjadi sebuah strategi pengelolaan kelompok paduan suara yang secara umum dapat dijadikan sebagai dasar pijakan.

\section{Pembahasan}

Penelitian yang diadakan sejak bulan April 2015 ini telah mendapatkan berbagai subjek penelitian yang cukup bervariasi. Fenomena paduan suara yang dihadapi oleh peneliti berasal dari berbagai jenis paduan suara yang jika ditelaah menjadi sebuah informasi yang cukup menarik. Hal ini dikarenakan posisi peneliti pada saat menjadi bagian dari aktivitas-aktivitas berikut:

Tabel. 1

Fenomena Aktivitas Paduan Suara

\begin{tabular}{|l|l|l|l|}
\hline No. & $\begin{array}{l}\text { Aktivitas } \\
\text { Paduan Suara }\end{array}$ & $\begin{array}{l}\text { Periode } \\
\text { Waktu/ } \\
\text { Tempat }\end{array}$ & $\begin{array}{l}\text { Posisi } \\
\text { Peneliti }\end{array}$ \\
\hline 1. & $\begin{array}{l}\text { Konser Paduan } \\
\text { Suara } \\
\text { Mahasiswa } \\
\text { Universitas } \\
\text { Gadjah Mada } \\
\text { bertajuk "Baru” } \\
\text { (The Beginning } \\
\text { of A Journey } \\
\text { Concert) }\end{array}$ & $\begin{array}{l}\text { 9 Meis } \\
\text { JBN Hall } \\
\text { Kridosono } \\
\text { Yogyakarta }\end{array}$ & $\begin{array}{l}\text { Peng- } \\
\text { amat } \\
\text { Paduan } \\
\text { Suara }\end{array}$ \\
\hline
\end{tabular}

\begin{tabular}{|c|c|c|c|}
\hline 2. & $\begin{array}{l}\text { Pelatihan olah } \\
\text { vokal Mannen } \\
\text { Choir (Kor laki- } \\
\text { laki dewasa) } \\
\text { Gereja Kristen } \\
\text { Indonesia } \\
\text { (GKI) Serpong } \\
\text { dalam rangka } \\
\text { pelayanan di } \\
\text { GKI } \\
\text { Prambanan } \\
\end{array}$ & $\begin{array}{l}30 \text { Mei } 2015 \\
\text { LPP Sinode } \\
\text { Samirono } \\
\text { Baru } \\
\text { Yogyakarta }\end{array}$ & $\begin{array}{l}\text { Pemberi } \\
\text { Materi } \\
\text { Olah } \\
\text { Vokal }\end{array}$ \\
\hline 3. & $\begin{array}{l}\text { Lomba Mars } \\
\text { Badan } \\
\text { Koordinasi } \\
\text { Keluarga } \\
\text { Berencana } \\
\text { Nasional } \\
\text { Tingkat DIY }\end{array}$ & $\begin{array}{l}11 \text { Juni } 2015 \\
\text { Sasana } \\
\text { Wiratama, } \\
\text { Monumen } \\
\text { Diponegoro, } \\
\text { Tegalrejo, } \\
\text { Yogyakarta }\end{array}$ & $\begin{array}{l}\text { Juri } \\
\text { Lomba } \\
\text { Paduan } \\
\text { Suara }\end{array}$ \\
\hline 4. & $\begin{array}{l}\text { Konser Paduan } \\
\text { Suara } \\
\text { Mahasiswa } \\
\text { Universitas } \\
\text { Muhammadiya } \\
\text { h Yogyakarta } \\
\text { Sunshine Voice } \\
\text { bertajuk } \\
\text { Survival }\end{array}$ & $\begin{array}{l}14 \text { Juni } 2015 \\
\text { A.R. } \\
\text { Fachruddin B } \\
\text { UMY } \\
\text { Base Floor }\end{array}$ & $\begin{array}{l}\text { Peng- } \\
\text { amat } \\
\text { Paduan } \\
\text { Suara }\end{array}$ \\
\hline 5. & $\begin{array}{l}\text { Festival dan } \\
\text { Lomba Seni } \\
\text { Siswa Nasional } \\
\text { (FLS2N) } \\
\text { Cabang Lomba } \\
\text { Vokal Grup } \\
\text { SMP tingkat } \\
\text { DIY tahun } 2015\end{array}$ & $\begin{array}{l}28 \text { Juli } 2015 \\
\text { SMK N } 2 \\
\text { Kasihan } \\
\text { Bantul } \\
\text { Yogyakarta }\end{array}$ & $\begin{array}{l}\text { Juri } \\
\text { Lomba } \\
\text { Vokal } \\
\text { Grup }\end{array}$ \\
\hline 6. & $\begin{array}{l}\text { Pemusatan } \\
\text { Latihan } \\
\text { Festival dan } \\
\text { Lomba Seni } \\
\text { Siswa Nasional } \\
\text { (FLS2N) } \\
\text { Cabang Lomba } \\
\text { Vokal Grup } \\
\text { Tingkat SMP di } \\
\text { Pekanbaru } \\
\text { Riau }\end{array}$ & $\begin{array}{l}10-14 \\
\text { Agustus } 2015 \\
\text { Hotel Furaya } \\
\text { Jl. Jendral } \\
\text { Sudirman } \\
\text { No. 72-74 } \\
\text { Pekanbaru } \\
\text { Riau } \\
\text { Sumatera } \\
\text { Utara }\end{array}$ & $\begin{array}{l}\text { Pemberi } \\
\text { materi } \\
\text { untuk } \\
\text { Lomba } \\
\text { Vokal } \\
\text { Grup }\end{array}$ \\
\hline 7. & $\begin{array}{l}\text { Festival } \\
\text { Paduan Suara } \\
\text { tingkat SMA } \\
\text { bertajuk } \\
\text { "Indonesian } \\
\text { Voice” } \\
\text { Agustusan } \\
\text { Anak-Anak } \\
\text { Merdeka }\end{array}$ & $\begin{array}{l}29 \text { Agustus } \\
2015 \\
\text { Bentara } \\
\text { Budaya } \\
\text { Yogyakarta }\end{array}$ & $\begin{array}{l}\text { Komen- } \\
\text { tator } \\
\text { Peserta } \\
\text { Paduan } \\
\text { Suara }\end{array}$ \\
\hline
\end{tabular}




\section{Konser Paduan Suara Mahasiswa Universitas Gadjah Mada BARU (The Beginning of a Journey Concert)}

Konser ini sendiri bertujuan sebagai sarana sosialisasi mahasiswa baru terhadap kegiatan kemahasiswaan diluar perkuliahan (Unit Kegiatan Mahasiswa/ UKM) Paduan Suara sekaligus sebagai ajang silaturahmi antar anggota paduan suara baik yang lama maupun yang baru. Hal teknis yang dengan segera tampak dari kondisi paduan suara ini adalah jumlah peserta yang terlibat yang jika digabungkan akan mencapai jumlah sekitar 80 orang. Formasi jumlah yang relatif cukup besar membutuhkan sebuah kedisiplinan yang cukup tinggi dan akurasi pengamatan yang cukup tajam dari pelatih agar dapat mencapai hasil yang maksimal. Kendala utama yang muncul terletak pada manajemen waktu karena proses bermusik yang dialami ke-80 orang tersebut cukup bervariasi satu dengan yang lain. Tantangan lain yang muncul adalah terkait pengaturan jadual latihan mengingat tantangan studi pada perguruan tinggi favorit dan berkualitas unggul di Indonesia tersebut menyita waktu dan menuntut kecerdasan pribadi yang cukup tinggi.

\section{Pelatihan olah vokal Mannen Koor (Kor laki-laki dewasa) Gereja Kristen Indonesia (GKI) Serpong}

Varian jenis paduan suara ini tergolong jarang dilakukan di Indonesia sehingga peneliti tertarik untuk melihat lebih dekat mengenai materi pembelajaran olah vokal yang telah mereka lakukan selama ini. Kegiatan pelatihan olah vokal ini mereka lakukan dalam rangka anjangsana dan pelayanan ibadah ke GKI Prambanan. Hal-hal teknis yang didapatkan pada saat penelitian ini dilakukan adalah bahwa mentalitas pemimpin paduan suara yang berlatar belakang penyanyi solo bermarga Batak cukup mendominasi paduan suara ini.
Kendala yang mereka ungkapkan saat menyanyikan lagu ini adalah pada pengaturan napas yang mereka rasakan kurang memadai karena tempo lagu ini yang memang diatur lambat.

Peneliti melakukan pengecekan awal terhadap kondisi awal para peserta melalui aktivitas bernyanyi yang mereka lakukan selama ini. Perkiraan peneliti cukup jauh meleset jika didasarkan pada tampilan yang diunggah pada laman Youtube. Gambaran mengenai paduan suara terlatih sirna manakala peneliti mencoba mencermati satu per satu karakter suara yang dimiliki oleh masing-masing peserta.Hal-hal teknis lain yang pada akhirnya disadari oleh peneliti bahwa paduan suara ini masih membutuhkan banyak referensi dan pelatihan yang intensif karena berdasarkan pengamatan terhadap cara berlatih mereka, peneliti menemukan bahwa pada dasarnya mereka belum begitu paham mengenai konsep paduan suara.

\section{Lomba Mars Badan Koordinasi Keluarga Berencana Nasional (BKKBN) Tingkat DIY}

Lomba paduan suara Mars Keluarga Berencana telah diadakan sejak tahun 2008 dengan misi dari lembaga untuk menggalakkan kegiatan keluarga berencana hingga menyentuh pada lapisan masyarakat yang paling bawah. Berdasarkan pengamatan yang dilakukan di lapangan, beberapa peserta merupakan pemain lama yang sudah sangat paham dengan situasi lomba. Pelaksanaan lomba 2015 ini bertempat di Sasana Wiratama, Museum Diponegoro, Yogyakarta.

Peserta yang tampil memiliki tingkat ketrampilan yang cukup beragam. Hal ini disebabkan karena visi dan misi yang dicanangkan oleh pihak BKKBN pada pelaksanaan Proses Advokasi dan Komunikasi Informasi dan Edukasi (KIE) pada masyarakat. Sasaran yang dilakukan lembaga ini memang akhirnya berusaha menyentuh masyarakat lapisan paling bawah yang nota- 
bene tidak memiliki pengalaman dan pengetahuan bernyanyi yang cukup serius. Praktik di lapangan menunjukkan bahwa banyak anggota paduan suara yang kemudian agak dipaksa untuk dapat bernyanyi hingga pada tahap tertentu yang dibutuhkan untuk dapat mengikuti kegiatan lomba ini. Kontras penguasaan teknis begitu terlihat antara peserta yang sudah mengenal medan perlombaan dengan peserta yang baru saja bergabung mengikuti lomba pada tahun ini.

\section{Konser Paduan Suara Mahasiswa Uni- Universitas Muhammadiyah Yogyakarta Sunshine Voice bertajuk Survival}

Konser Paduan Suara Mahasiswa Universitas Muhammadiyah ini digelar pada tanggal 14 Juni 2015. Konser ini merupakan sebuah konser 'pamit' bagi para mahasiswa peserta Unit Kegiatan Mahasiswa (UKM) Paduan Suara untuk terlibat dalam Festival Paduan Suara Internasional yang digelar di Thailand pada bulan Juli setelah Lebaran. Pengamatan awal pada saat hadir di tempat konser menunjukkan bahwa penonton sangat antusias ingin melihat konser ini dan memberikan apresiasi terhadap upaya para anggota untuk melakukan aktivitas konser.

Pengamatan lapangan menunjukkan bahwa paduan suara ini telah dipersiapkan dengan cukup matang untuk bisa mengikuti Festival Paduan Suara Internasional. Lagu andalan yang berupa lagu daerah mereka bawakan dengan cukup yakin dan percaya diri. Paduan suara ini memanfaatkan keunggulan mereka dalam penguasaan ekspresi pada lagu daerah sehingga menjadi sebuah suguhan yang cukup menarik dan mendapatkan sambutan yang cukup meriah.

\section{Festival dan Lomba Seni Siswa Nasio- nal (FLS2N) Cabang Lomba Vokal Grup SMP tingkat DIY 2015}

Festival Lomba Seni Siswa Nasional (FLS2N) SMP tingkat DIY ini diselengga- rakan pada tanggal 28 Juli 2015 di SMK Negeri 2 Kasihan Bantul/ Sekolah Menengah Musik (SMM) Yogyakarta. Sesuai dengan sasaran lomba yang merupakan peserta didik SMP negeri dan swasta di seluruh Indonesia yang dilaksanakan secara berjenjang, kegiatan lomba di wilayah Provinsi DIY ini merupakan hasil saringan lomba dari tingkat kabupaten, sehingga para peserta yang tampil sudah mewakili kelompok terbaik berdasarkan hasil seleksi sebelumnya.

Kriteria lomba yang disampaikan di atas memerlukan sebuah strategi antisipasi dari para pelatih vokal grup karena para pelatih perlu mempertimbangkan dan memperkirakan hasil capaian maksimal yang bisa dilakukan oleh para peserta didik yang mengikuti lomba ini.

Tantangan yang dihadapi para pelatih cukup kompleks dan bervariasi. Hal ini dapat dilihat dari beberapa indikator yaitu: waktu persiapan untuk maju ke tingkat provinsi dalam kisaran 1,5 bulan dan waktu persiapan untuk maju ke tingkat Nasional dalam kisaran 1 bulan. Disamping itu kondisi musikalitas siswa dan komposisi karakter suara yang dipilih dan perhitungan terhadap masa akil balik siswa yang berpengaruh terhadap kualitas dan karakter suara yang dibutuhkan dan gambaran mengenai hasil akhir pembentukan suara dalam hitungan minggu.

\section{Pemusatan Latihan Festival dan Lomba Seni Siswa Nasional (FLS2N) Cabang Lomba Vocal Grup tingkat SMP di Pekanbaru Riau}

Pemusatan Latihan Lomba Vokal Grup FLS2N di Riau ini dipilih untuk diangkat ke dalam pembahasan penelitian sebagai sarana untuk memperkaya dan juga mempertajam upaya pengamatan terhadap fenomena penanganan kualitas olah vokal peserta didik tingkat SMP yang terjadi secara umum di Tanah Air sebagai bagian dari pencanangan kegiatan kesenian ini 
secara Nasional. Pada saat dilakukan di Riau penanganan ini mempertimbangkan banyak aspek. Pembenahan yang dilakukan pada kelompok ini terpusat pada hal-hal detil yang dianggap perlu dibenahi mengingat waktu yang tidak memungkinkan karena peneliti harus mengukur kemampuan musikal peserta. Sebuah penanganan yang bersifat eksperimen dilakukan terhadap peserta yang membawakan bagian solo untuk membawakan bagian tersebut dengan nada yang cenderung tinggi untuk menarik perhatian juri. Namun demikian usaha ini mendapatkan kendala yaitu musikalitas peserta yang tidak dapat mengantisipasi perubahan dengan cepat dan merasakan bahwa permintaan peneliti sebagai narasumber dirasakan terlalu berat untuk dilakukan.

\section{Festival Paduan Suara tingkat SMA bertajuk “Indonesian Voice" Agustusan Anak-Anak Merdeka}

Festival Paduan Suara ini digagas oleh Grup Kompas Gramedia dan mengambil tempat di Bentara Budaya pada tanggal 29 Agustus 2015. Konsep acara paduan suara yang diselenggrakan di tepi jalan raya dan bersifat out door. Setiap peserta pada acara ini membawakan 3 buah repertoar dengan durasi rata-rata berkisar antara 15-20 menit dengan waktu persiapan yang mereka lakukan. Penyelenggaraan yang dimulai sekitar pukul 18.00 cukup menarik perhatian dan setiap paduan suara datang dengan para supporter mereka sehingga acara berlangsung sangat meriah.

Pemberian komentar pada acara ini merupakan sebuah strategi dari panitia untuk memperlihatkan sebuah acara yang khas dan unik sekaligus memancing minat peserta untuk mengikuti acara ini. Beberapa paduan suara memang menunjukkan aksinya yang bisa dibilang cukup professsionnal dan sesuai dengan prestasi yang mereka dapatkan yang dicantumkan dalam curri- culum vitae mereka. Meskipun pada akhirnya penyelenggaraan pentas paduan suara ini seperti perlombaan pada umumnya dengan memberikan penghargaan untuk peserta dengan penampilan terbaik, namun demikian para peserta tetap antusias melaksanakan acara ini karena dukungan dari para supporter mereka.

\section{Hasil Penelitian: Pertimbangan Musikal dan Teknis dalam Mengantisipasi Target Waktu}

Berdasarkan pengamatan yang dilakukan di lapangan, setiap pemimpin paduan suara mempunyai pendekatan yang berbeda dalam menangani masalah paduan suara yang dilatihnya.Sampai pada tahap tertentu faktor musikal yang paling banyak dikembangkan dan dipertimbangkan adalah bidikan nada dan ritmis. Perhatian terhadap faktor muskal tersebut berkaitan erat dengan target yang akan dicapai oleh sebuah paduan suara dan kondisi awal saat mereka memulai proyek mereka. Secara umum fokus perhatian dan pengelolaan faktor musikal dipengaruhi oleh waktu yang dibagi dalam 3 kategori yaitu:

a. Kategori Jangka Pendek (1 minggu 2 bulan)

b. Kategori Jangka Menengah (2 bulan 5 bulan)

c. Kategori Jangka Panjang (lebih dari 5 bulan)

Kategori Jangka Pendek ditemukan dari beberapa kasus persiapan paduan suara seperti pada pelatihan paduan suara Mannen Koor GKI Serpong, Lomba Mars KB Tingkat DIY, Pemusatan Latihan Festival dan Lomba Seni Siswa Nasional (FLS2N) Cabang Lomba Vocal Grup di Pekanbaru Riau serta beberapa 'job' paduan suara mahasiswa yang dibina oleh beberapa pelatih paduan suara yang menjadi target penelitian seperti pada paduan suara Universitas Gadjah Mada dan paduan suara Duta Voice (Universitas Kristen Duta 
Wacana). Pada kategori jangka pendek ini umumnya anggota paduan suara dihadapkan pada penguasaan target musikal untuk menguasai notasi nada dalam waktu yang bisa dikatakan relative singkat. Pada umumnya dalam 2 kali latihan bahkan dalam sekali latihan mereka sudah diharuskan menguasai notasinya.Namun demikian kecepatan menguasai nada bukan satu-satunya faktor penentu karena mereka tetap harus mempertimbangkan bahwa hal ini merupakan kerja kelompok secara berkesinambungan.Kelompok yang sudah lama mengadakan latihan mempunyai kondisi penguasaan yang lebih cepat dibandingkan dengan kelompok yang dibentuk hanya untuk mengikuti suatu lomba seperti pada waktu Lomba Mars KB dan Lomba FLS2N.Kondisi ini terlihat pada saat eksplorasi lagu baru yang dipersiapkan untuk mengikuti babak final.Antisipasi terhadap perubahan harmonisasi yang dilakukan pada saat latihan tidak dapat dengan segera dilakukan oleh semua anggota karena terdapat salah satu anggota yang tergolong lambat dalam melakukan penyesuaian terhadap bidikan nada baru yang diberikan.

Beberapa peserta lomba khususnya lomba Mars KB juga terlihat belum stabil dalam membidik nada. Hal ini dikarenakan persiapan yang terlalu mepet dan proses pembentukan materi suara yang memang dipaksakan untuk mencapai target. Intensitas tatap muka menjadi sebuah tantangan karena pada umumnya peserta yang ikut bukanlah penyanyi yang setiap hari berlatih bernyanyi.Pada kategori jangka pendek ini target pelatih umumnya difokuskan pada penyamaan bidikan nada serta kekompakan memulai dan mengakhiri lagu.Penargetan yang terlalu tinggi hingga pada taraf interpretasi lagu dalam beberapa hal berdampak pada pengabaian kealamian cara bernyanyi yang semestinya dijaga dan memang tidak mudah untuk ditampilkan dalam waktu singkat.

Pelatih pemula dan anggota paduan suara yang belum lama mengikuti aktivitas paduan suara memiliki kecenderungan untuk mengabaikan detil bidikan nada, ketukan, harmonisasi maupun fokus pembentukan suara yang padu secara konsisten dari awal hingga akhir. Hal tersebut berkorelasi dengan apresiasi terhadap paduan suara yang pernah didengar, pengetahuan musik yang dimiliki oleh pelatih dan anggota paduan suara serta cara menyikapi instrumen yang pada umumnya disesuaikan dengan target namun kurang memperhatikan perkembangan pribadi penyanyi. Target yang terlalu dipaksakan juga membuat rencana yang sudah disusun kadang berubah terlalu cepat.

Kategori target jangka menengah dan jangka panjang umumnya dilakukan oleh pelatih yang sudah berpengalaman dan mengetahui betul upaya untuk dapat membuat anggota paduan suara dapat bernyanyi dengan nyaman.Eksplorasi halhal yang bersifat musikal dapat dengan leluasa dilakukan.Hal ini dapat dilihat pada paduan suara Sunshine Voice Universitas Muhammadiyah yang dalam konser pamit mereka mencoba menyuguhkan hasil pergulatan mereka untuk bisa mengikuti ajang Lomba Paduan Suara di Thailand pada akhir bulan Agustus 2015 setelah Lebaran kemarin. Perjuangan anggota paduan suara ini untuk bisa mendapatkan penghargaan internasional di ajang festival paduan suara dunia merupakan cita-cita yang telah dirancang sejak lama. Narasumber Iqbal Maulana Nafi sebagai mantan Ketua Paduan Suara tersebut menyatakan bahwa pelatih paduan suara mereka sekarang yaitu Wisnu Cahyadi telah dengan konsisten membangun konsep bermusik selama 8 tahun terhitung dari sejak awal bergabung menjadi pelatih. Keikutsertaan dalam ajang festival tingkat 
dunia tentu dilakukan dengan sebuah pertimbangan bahwa mereka sudah mempunyai cukup bekal untuk bisa mengkuti festival tingkat dunia.Persiapan ini dilakukan dengan suatu keberanian untuk bisa membuktikan bahwa mereka layak untuk mendapatkan penghargaan emas dan perak dalam kategori folklore (lagu-lagu daerah) dan musica sacra.

Bentuk komunitas paduan suara ikut mempengaruhi upaya-upaya membangun konsep bermusik.Pelatih Paduan Suara dengan target festival umumnya membekali anggotanya dengan pengetahuan musik dan kemampuan untuk mengantisipasi target tersulit yang mereka tentukan dalam suatu rentang waktu tertentu. Upaya yang nyata dilakukan oleh pelatih paduan suara mahasiswa Universitas Gadjah Mada, Marcel Yudaperwira yang dengan konsisten telah membekali anggota angkatan baru dengan pengetahuan mengenai teknis membaca notasi balok dan pengetahuan mengenai membaca partitur hingga sampai pada tingkat penguasaan instrumen olah vokal yang dikerjakan dengan sangat detil dan konsisten.

Dinamika untuk membangun sebuah konsep bermusik mendapatkan tantangan yang lebih besar terutama berkaitan dengan waktu studi mahasiswa sarjana strata satu yang dibatasi maksimal hingga 5 tahun. Pembatasan tersebut telah menyebabkan target penguasaan materi dan pengolahan fisik dan mental anggota paduan suara harus diperhatikan dengan lebih detil. Perhitungan yang dilakukan oleh pelatih bersama dengan pengurus paduan suara menemukan bahwa seorang anggota paduan suara akan efektif mengikuti pelatihan selama 2 tahun sebelum kuliah mereka lebih banyak didominasi oleh kegiatan praktikum dan kegiatan yang berkaitan dengan tugas akhir yang umumnya diselesaikan dalam kisaran waktu 3-4 tahun.
Unsur-unsur teknis pendukung yang dapat menunjang dan juga memperbesar kemungkinan pencapaian sukses pergelaran paduan suara atau pencapaian prestasi paduan suara adalah: konsentrasi, suasana bernyanyi dan cara mencapai target bermusik, serta upaya-upaya untuk membuat para peserta atau anggota paduan suara menikmati setiap detil perkembangan yang dialami. Untuk menjawab pertanyaan ini peneliti melakukan wawancara yang membahas topik mengenai kendala yang didapati oleh para pelatih paduan suara dalam mengelola paduan suara mereka selama ini. Berdasarkan hasil pengamatan dan wawancara yang dilakukan dengan beberapa responden, strategi pengelolaan komunitas paduan suara untuk mencapai penampilan akhir yang terbaik dapat dilakukan dengan memperhatikan beberapa hal sebagai berikut:

a. Komitmen

b. Strategi pengelolaan materi musikal yang terstruktur

c. Atmosfer latihan yang kondusif

d. Estimasi target berdasarkan kondisi riil di lapangan

e. Proyeksi kemampuan individu secara musikal maupun teknis

\section{Penutup}

Berdasarkan hasil pengamatan dan penelitian yang dilakukan maka pertimbangan dan pengembangan faktor musikal yang menjadi fokus perhatian dalam mempersiapkan aktivitas yang berbentuk paduan suara saat ini adalah berhubungan dengan target pencapaian dan waktu yang tersedia. Faktor musikal yang dapat dipertajam dalam pengembangannya adalah mengenai bidikan nada, penguasaan teknis pendengaran, pengolahan ritmis dan kepekaan untuk mendengarkan perpaduan bunyi. Para pelatih olah vokal perlu mempertimbangkan aspek penyelarasan dalam proses mewujudkan ide atau 
agagasan musikalnya agar dapat dengan mudah ditangkap dan sesuai dengan karakter paduan suara dan anggota paduan suara yang dibina. Unsur-unsur teknis pendukung yang dapat menunjang dan memperbesar kemungkinan kesuksesan pergelaran adalah :

a. Adanya sebuah jadwal kegiatan yang jelas yang dapat dipahami oleh semua anggota yang terlibat.

b. Antisipasi terhadap perkiraan perkembangan yang terjadi dari dinamika proses kreatif yang berlangsung, yaitu dengan cara mempersiapkan berbagai macam kemungkinan perencanaan (tidak hanya mempersiapkan rencana tunggal)

c. Antisipasi terhadap dinamika kelompok sebagai akibat dari keterlibatan secara bersama-sama dalam suatu rentang waktu tertentu.

d. Kontrol perkembangan kegiatan melalui aktivitas publik yang terukur dan terdokumentasi secara berkala seperti uji coba pentas atau keikutsertaan dalam sebuah festival atau lomba.

e. Pengamatan terhadap kegiatan apresiatif secara langsung untuk merasakan sisi lain saat para peserta menjadi penonton.

Hasil yang dicapai oleh sebuah paduan suara atau vokal grup akan sangat bervariasi bergantung kepada proses dinamika yang dijalani dalam mempersiapkan dan melaksanakan sebuah kegiatan

Langkah-langkah sistematik yang dapat dilakukan oleh pihak-pihak yang terlibat dalam paduan suara agar dapat berjalan dengan optimal adalah dengan memperhatikan beberapa kondisi sebagai berikut: a. Melakukan screening awal melalui pengetesan ambitus, baca notasi, kemampuan beradaptasi dan juga pengukuran kualitas fokus secara individual terhadap materi baru yang diberikan.

b. Pemetaan awal kekuatan dengan melihat rentang usia, aktivitas kegiatan bermusik, waktu yang dapat disediakan oleh anggota, kondisi psikologis dan lingkungan pengembangan.

c. Mengenali potensi diri yang dapat dilakukan dengan jalan mengikuti kegiatan yang bersifat kompetitif apresiatif.

d. Merumuskan dasar pijak yang kuat untuk mengembangkan kemampuan pribadi dan mencapai tujuan kelompok. Kendala yang dihadapi dalam proses mencapai sebuah target tertentu akan sangat terbantu dengan adanya upaya untuk menumbuhkan komitmen melalui kegiatan apresiatif secara bersama-sama yang umumnya diwujudkan dengan pelatihan manajerial individual.

\section{Referensi}

Afiff, Faisal, 2012, "Pilar-pilar Ekonomi Kreatif", Binus University, tersedia pada http://sbm.binus.ac.id/files/2013 /04/Pilar-Pilar-Ekonomi-Kreatif.pdf pada tanggal 27 Januari 2015 Pukul 23.18 (GMT + 7).

Creswell, John W., 1998, Qualitative Inquiry and Research Design, SAGE Publications, Inc., California.

Indrawati, Desti; Ismudiati, Endang; Bintarto, Gathut 2013, Kualitas Kompetitif Paduan Suara Anak (Studi Kasus: Paduan Suara Vocalista Angels di Klaten, Jawa Tengah), Skripsi Jurusan Musik FSP ISI Yogyakarta. 
Ismudiati, Endang, 2013, Peningkatan Kualitas Hidup Lansia melalui Aktivitas Paduan Suara di Gereja, Jurnal Promusika, Vol.1 No.1 April 2013 hal.25-32

Louhivuori, Jukka dkk. 2005, “'Singing Together' : A Crosscultural Approach to the Meaning of Choirs as a Community" dalam Campbell, Patricia Shehan dkk. (eds). Cultural Diversity in Music Education, Directions and Challenges for the $21^{\text {st }}$ century.
Australian Academic Press Pty Ltd. Brisbane.

Turino, Thomas. 2008, Music as Social Life, The Politics of Participation, The University of Chicago Press, Chicago. Watanabe, Ruth, T., 1967, Introduction to Music Research, Prentice-Hall, Inc., Englewood Cliffs, New Jersey.

Yin, Robert K. 2003, Studi Kasus (Desain dan Metode), PT. Raja Grafindo Persada, Jakarta. 